\title{
Trust and National Belonging: Welfare for Disabled Veterans in Bohemia (1914-1918)
}

THOMAS ROHRINGER

\section{Introduction}

Caring for those who suffered physical injuries while defending our severely threatened fatherland and for the families of those who died a hero's death on the battlefield is not only generally one of the gravest duties of society but also an imperative for the state of highest importance. ${ }^{1}$

These were Prime Minister Karl Stürgkh's opening words to outline the Cisleithanian administration's new duties concerning the welfare for disabled soldiers and surviving dependents in December 1914. According to him, welfare for disabled veterans of the AustroHungarian army had to be transformed fundamentally compared to the support disabled soldiers had received up to this point, which was mainly limited to a military pension and placement in a disabled soldiers' home. Stürgkh therefore tasked the Minister of the Interior Karl Heinold von Udyński with launching a governmentally coordinated welfare campaign for Cisleithania. ${ }^{2}$ This campaign had to succeed; otherwise, public trust in the monarchy would be forfeit, according to Heinold. ${ }^{3}$

By early 1915, interior ministry officials had prepared a programme for re-integration, composed of medical therapy, occupational counselling, professional training and employment services to »direct [disabled soldiers] back to gainful activity as useful members of society «. ${ }^{4}$ For this purpose, the government welfare campaign needed sickness and accident insurance carriers and their sanatoria, provincial administrations and associations within the civil society to cooperate. ${ }^{5}$ Welfare for disabled soldiers was consequently not a project monolithically implemented by state administration throughout Cisleithania, but its regional realization relied on government and non-government actors and could be considered an "assemblage,$_{,}^{6}$ a "sum consisting of heterogeneous parts with features resulting from the interaction of those parts «. ${ }^{7}$

This introduces a different perspective on the Habsburg Monarchy during wartime as well, Ke-chin Hsia argued. ${ }^{8}$ Characterizing the Cisleithanian half of the Habsburg Empire during the first two years of the war, a "military-bureaucratic dictatorship « ${ }^{9}$ is not only disregarding the systematic integration of civil society actors into the expansion of social welfare by government institutions but also their room to manoeuvre. ${ }^{10}$ This, however, should in no way serve to negate the army's brutal actions against the population in the theaters of war on the eastern front and at the 
Balkans or the backlash against persons suspected of disloyalty by public authorities. ${ }^{11}$ It rather should be taken into consideration that this concurrency of different and sometimes contradictory policies compelled government actors (an increasing number of them, women, as the war went on) to constantly balance centralized directives and programs, institutional norms and their ties to the (local) population. ${ }^{12}$

However, "[t]he particular appreciation of socially and emotionally distant relationships « ${ }^{13}$ was a crucial quality of modern administrations, according to Peter Becker and Rüdiger von Krosigk. Everyday administration established this distance in specific methods of registering, decision making and communicating via written correspondence. ${ }^{14}$ As the monarchy's reach expanded with social welfare, infrastructure and public health institutions since the 1880s, federal, provincial and autonomous municipal administrative bodies became the main interfaces between citizens and state. ${ }^{15}$ As recent historiography has challenged the narrative of the anachronistic and moribund Habsburg monarchy, the notion of sloyalty< has gained attention for analyzing the relation between the monarchy and its citizens. ${ }^{16}$ Laurence Cole and Daniel Unowsky showed how the Habsburg family and political elites strove to instill patriotism and loyalty in imperial subjects through Habsburg patronage of local veterans' organizations and public festivities in the second half of the 19th century. ${ }^{17}$ It was a particular kind of loyalty revolving around the Habsburg dynasty and, notably, the army. Maureen Healy deftly pointed out the significance of projecting the image of an approachable emperor until the end of the First World War as well as its pitfalls, because access to the emperor was in fact regulated through a highly bureaucratized procedure. ${ }^{18}$

This tension between fostering personal loyalty towards the emperor and an increasing relevance of administrative procedure opens a space to ask about the role of trust. While Ute Frevert highlighted the proliferation of semantics and discourses of trust in the German states and the German Empire intertwined with their gradual democratization and bureaucratization in the late 19th and early 20th centuries, much less is known about trust in the Habsburg Monarchy. ${ }^{19}$ Following Jakob Tanner, this contribution will regard interconnects social phenomena, and allows to respond to a problem while ensuring its plausibility at the same time. ${ }^{20}$ Therefore, trust's specific historical function in the re-integration efforts will be examined. ${ }^{21}$

Between 1900 and 1914, trust gained currency in the political, bureaucratic and academic circles of state reformers around Ernest von Koerber and Josef Redlich. ${ }^{22}$ Koerber, as John Deak put it, "used administrative reform in place of constitutional or political reform ${ }^{23}$ and trust (or the lack thereof) served to describe the problem, i.e. the monarchy's (perceived or real) lack of legitimacy among the populace, and the way to its solution. The monarchy's administration, Koerber remarked in his "Studien über eine Verwaltungsreform", had the flaw that those »institutions of social welfare, the benefits of which are felt immediately by the population and which the populace therefore treasures «, ${ }^{24}$ were not federal administrative bodies, but institutions of autonomous municipalities. Thus, the citizens, according to Koerber, considered the state either an institution hostile to them or a "source of money to ruthlessly tap into « ${ }^{25}$ Federal officials, in turn, would consider public welfare a task abstracted from individual interests. Koerber's solution to this faulty relation between administration and citizens was establishing a federal administration at the level of local court circuits and to shift responsibilities from autonomous to federal bureaucracy to bring the monarchy closer to its citizens. ${ }^{26}$ Although these plans never led to an actual administrative reform, examining trust reveals that political elites searched for ways of generating emotional connections with the monarchy's citizens, not only through the dynasty but also through new bureaucratic practices and behavior.

As the first section shows, the socially ambivalent position of disabled veterans in the novel project of social re-integration and the mobilization of new groups of actors resulted in officials, medical practitioners and civil society actors reflecting upon bureaucratic practices and behaviors anew. For them the concept of trust played a vital role; they thought they needed disabled soldiers' trust to establish their position as experts. Trust is not defined as an emotion per se, but since medical practitioners and voluntary and administrative agents considered a skillful management of emotions essential, trust will be analyzed as a relational "emotional demeanor « in this context. ${ }^{27}$ 
The second and third sections demonstrate how Karl Eger, official (Referent) for disabled veteran welfare at the military command Leitmeritz/Litoměřice, used the concept of trust to establish a grass-roots administrative organization and specific administrative practice in Bohemia's disabled veteran welfare. Eger's normative ideas are contrasted with their implementation through a case study, not to examine the success or failure of normative guidelines, but the adaptive efforts local actors used to successfully manage their tasks, and the room to manoeuvre they enjoyed within their institutions. ${ }^{28}$ The fourth section demonstrates how Eger used the concept of trust to interconnect his grass-rootslevel administrative project with national belonging and utilized it to nationalize the population.

\section{Expertise and Trust}

Re-integrative measures aimed at restoring the disabled soldiers' capability to work utilizing medical therapy, job training at public schools and employment services, so that they would be integrated into society again..$^{29}$ In his written reply to Stürgkh, Minister of the Interior, Heinold emphasized the novelty of such a project and the necessity of involving the civil society to obtain its human and financial resources, its scope of action and influence for the welfare for disabled veterans, because state administration could not provide these means on its own. ${ }^{30}$ To achieve this, Heinold ordered the formation of the so-called >Provincial Commissions for the Welfare of Homecoming Warriors` (Landeskommissionen zur Fürsorge für heimkehrende Krieger, from here on: Landeskommissionen) in the individual crown lands in February 1915 to muster medical experts, specialists for vocational training, businessmen and charitable clubs; women were members of the Landeskommissionen in specific ladies' committees. These Landeskommissionen were designed to act as an interface between military and civil administration, between military hospitals and vocational training facilities and between state administration and civil society to coordinate reintegrative measures. ${ }^{31}$

Initiatives for disabled veteran welfare did, however, not only originate from centralized government actors; instead, many local private associations had been founded since the start of the war to financially support disabled soldiers. ${ }^{32}$ In Bohemia, in May 1915, the equivalent of the Landeskommissionen was constituted, the sLandeszentrale für das Königreich Böhmen zur Fürsorge für heimkehrende Krieger//Státní zemská ústředna pro království České pro péči o vrátivší se vojíny، (from here on: Landeszentrale). ${ }^{33}$ Within the Landeskommissionen, special committees for curative treatment, training and employment services were installed. In the Landeszentrale, the committee for curative treatments was staffed with surgeons, orthopaedists, internists and accident insurance experts; the committee for training and employment services was filled with medical practitioners, principals of public vocational and commercial schools, members of the German and Czech sections of the agricultural council (Landeskulturrat), representatives of the chambers of commerce and of the sickness insurances. ${ }^{34}$ These experts formed, together with military officers, occupational counselling committees (Berufsberatungskommissionen) to evaluate the working capacity of disabled soldiers to assign them correspondingly to individually fitting vocational training programs. ${ }^{35}$

The Landeskommissionen not only needed these actors as experts for evaluating and restoring working capacities but also due to their institutional resources: Physicians Rudolf Jedlička and Josef Gottstein were medical directors of institutes for physically disabled children in Prague and Reichenberg/Liberec, respectively, which were converted into treatment institutions for injured soldiers. ${ }^{36}$ Robert Marschner, executive director of the Landeszentrale, managed the Prague Accident Insurance Institute, with its officials handling the administrative duties of the Landeszentrale. ${ }^{37}$ Public vocational schools, chambers of commerce, departments for the advancement of crafts and the agricultural council provided the means for vocational training courses in the form of teaching staff, rooms and instructional material. ${ }^{38}$

From the start, the medical practitioners and professionals claiming authority to determine the occupational future of disabled soldiers were confronted with disabled veterans' different opinions about the purpose of re-integration. While returning to the profession once held was the ideal of re-integrative 
actions, the deputy director of the ,Viennese bureau of employment services for war invalids (Wiener Amtsstelle der Arbeitsvermittlung für Kriegsinvalide), Richard Sudek, reported at the end of 1915 that disabled soldiers opposed returning to their former job "vigorously«. ${ }^{39}$ The Landeszentrale’s first annual report suggests similar conflicts. It attributed problems with employment services for disabled veterans to "personal qualities of the invalids, degenerating [»ausarten«] into the so-called pension psychosis « ${ }^{40}$ For Anthony Giddens, the doctor-patient relationship is one of the paradigmatic situations where personal interaction is able to refresh or undermine trust in abstract expert systems. ${ }^{41}$ The positioning as experts claimed by medical and occupational professionals of the Landeskommissionen proved to be extremely fragile after only a few months into the re-integrative actions.

While these conflicts initially resulted in medical practitioners using attributes like saversion to work or spension neurosis` to deny the disabled soldiers' claims any legitimacy, ${ }^{42}$ by 1916 , medical practitioners, civil society actors and social scientists started to interpret these conflicts as expressions of a lack of trust. Hungarian social scientist and head of Budapest's sociopolitical division, Emerich/Imre Ferenczi, stated in a 1916 lecture about welfare for disabled veterans that one of its biggest challenges was the "mistrust [the disabled men hold] against the state $«{ }^{43}$ The occupational counseling committees were, according to Ferenczi, not able to »inspire, on a psychological level, the disabled veteran's trust «, ${ }^{44}$ which would have been needed to convince him to return to his former job.

Medical practitioners, teachers, occupational counselors and job placement officers attributed a significant psychological dimension to the disabled veterans' re-integration. Obstacles to overcome for a successful return to gainful employment were, in their eyes, not only the disabled soldiers' physical impediments but also particularly their conviction to not be able to work again. Therefore, medical and vocational experts saw it as their duty to counter this notion in therapy and vocational training. For this reason, they identified gaining the disabled soldiers' trust as one of their tasks and looked for ways of achieving it. ${ }^{45}$ In these efforts, occupational counseling proved to be an important interface between therapy and vocational training.

Combining all three steps of re-integration (counseling, therapy and vocational training) in one institution, the Viennese Reserve Hospital No. 11 was considered one of the leading institutions of disabled soldier welfare in Cisleithania. Medical practitioners claimed occupational counseling for the medical sphere, relegating vocational experts to an advisory role. ${ }^{46}$ In a 1916 article in the Wiener Medizinische Wochenschrift, Josef Pokorny, conducting medical occupational counseling at the Reserve Hospital, reflected upon the different dimensions of trust medical occupational counselors had to implement and mobilize. To successfully refresh such a »second-order trust «, a trust in expert knowledge, ${ }^{47}$ during personal contact between slaymen` and sexperts`, Giddens pointed out that experts need to stage their reliability with outstanding diligence through performing "an attitude of ıbusinessas-usual « «. ${ }^{48}$ Pokorny, however, explained that the point was not only to demonstrate professional conduct and expertise in a specific disabled veteran's trade. Disabled soldiers needed to get "a sense of well-meaning, of being in the hands of a benevolent counselor «. ${ }^{49}$

Adolf Deutsch brought forward a similar argument. Deutsch was working at the Reserve Hospital No. 11 as well and at the Viennese bureau of employment services for disabled veterans. After the war, he would become public health officer at the 'Viennese invalids' department` (Wiener Invalidenamt). He advised against occupational counseling "with a categorical emphasis«,50 instead disabled soldiers should be granted time to discuss with family members, friends or colleagues, because »this inspires trust even in the most mistrusting and increases their compliance with the suggestions they are told «. ${ }^{51}$ In his handbook for medical occupational counselors, Deutsch advised to use conversation techniques relying on controlling one's own emotions and mobilizing the disabled veterans' emotions specifically. Therefore, Deutsch saw an important achievement in "the first smile [flitting] over [a disabled veteran's] haggard features «. ${ }^{52}$ Physicians were supposed to exercise listening, patience and sympathy. These were not passive qualities for Deutsch, but active efforts, requiring "practice" and "quick-wittedness of the physician $"{ }^{53}$ All this aimed at 
conducting the conversation in a way to stop negative consequences of an injury or ailment from determining the self-perception of the patient and making him acknowledge the physician as an expert. These conversation techniques relied on deliberate methods of "mobilizing", "controlling", and "communicating" emotions, ${ }^{54}$ an "emotional labor «55 of the physician to gain the disabled soldiers' trust and "lifting [their] lowered will to life and work «. ${ }^{56}$

Karl Eger also addressed the issue of conversations during occupational counseling in his "Handbook for occupational counselors «, published in 1916. ${ }^{.7}$ Deviating from Deutsch, Eger did not limit his statements to the situation of counseling, but located the trust issue of the welfare for disabled veterans in the administrative structure and advocated for its comprehensive transformation and the formation of a local disabled veteran welfare system.

\section{Governance and Trust: Grass- roots Disabled Veteran Welfare}

Karl Eger had been appointed as an official for disabled veteran welfare by Eugen von Scheure, commander of the military command Leitmeritz/Litoměřice, early in 1916. Scheure himself acted as protector of the private charitable society 'Invalid welfare for Leitmeritz (Invalidenfürsorge für Leitmeritz) and considered local welfare for disabled veterans essential. ${ }^{58}$ Karl Eger proved to be a skilled organizer; in the same year he was appointed, Eger published his pamphlet "To our wounded and sick warriors" (An unsere verwundeten und kranken Krieger) to inform disabled soldiers about measures for re-integration and his "Handbook". Both were translated into Czech in 1917, initiated by the Bohemian Landeszentrale. ${ }^{59}$ In his handbook, Eger already enumerated 117 local committees in the military command's administrative district. It remains unclear if he included the regional committees of the Bohemian Provincial Employment Office (Landeszentralarbeitsamt), which had been charged with providing employment services for disabled veterans since November $1915 .{ }^{60}$ Within a short period of time, Eger had established himself as an important together with Robert Marschner, executive director of the Landeszentrale, he participated in a meeting of representatives from all provincial commissions (Landeskommissionen) with officials from the ministries of the interior, agriculture, labor and war in Vienna on 18 May 1917. ${ }^{61}$ At the turn of the year 1917/1918, Eger's experiences and suggestions were requested by the Ministry of Social Welfare, established by Charles I at the end of 1917, to plan a comprehensive reform of social welfare. Appointing Eger to the ministry was discussed, but not put into effect. ${ }^{62}$ Karl Eger used these internal reports and lectures to push his project of a decentralized, grass-roots disabled veteran welfare, based on local welfare boards.

These local welfare boards were supposed to contact disabled soldiers even before they left hospital to initiate further actions for their training and employment. ${ }^{63}$ Eger's pivotal point for the creation of a grass-roots disabled veteran welfare was that the disabled men's trust would exclusively be bestowed upon such a locally rooted welfare. To accomplish the purpose of re-integrative actions and to return disabled soldiers to the labor market, "the trust the invalid shows in his home ["Heimat«] and his fellows at home [»Heimatsgenossen «] [has to be] utilized « ${ }^{64}$ For trust alone could guarantee that the disabled soldiers obeyed the suggestions of their occupational counselors. To this end, the local population had to be won over for re-integrative measures first, however. Because, as Eger argued, "[w]hen [...] your neighbor [...] says: , [...] why are you plodding on, you surely get a pension now «, this would threaten the success of social re-integration, for the "word[s] [of the neighbor have] greater [weight] than all the reasoning of studied gentlemen! « 65

Raising the local population's awareness about the objectives and purpose of disabled veteran welfare and the possibilities to restore their capacity for work was therefore supposed to guarantee successful re-integrative measures in more than one way: mobilizing the local population for disabled veteran welfare, creating a social environment supportive of re-integration and convincing future employers that disabled veterans were still able and willing to work. ${ }^{66}$ Thus, Eger connected, via the concept of trust, the objective of the re-integrative actions of returning disabled soldiers to their former job, family and 
home, if possible, with the need for a decentralized administrative structure and locally staffed executive boards.

In Eger's statements, many similarities to the prewar discussions on trust and administrative reform can be found. Like Ernest von Koerber, he considered court circuits the most fitting smallest administrative units, and for Eger it was not only about a different organizing logic either but also a different way of administrative action. In his presentation in Vienna, Eger staged himself as a man of practice, a man capable of looking at administrative structures without prejudice for exactly this reason. ${ }^{67}$ This hands-on mentality was his guiding theme for assessing disabled veteran welfare, which he considered too distanced from the everyday world of disabled soldiers. He contrasted this "armchair « disabled veteran welfare (vom grünen Tisch aus) with local »based on real life« welfare action, with »occupational counseling in [their] home town" at its core. ${ }^{68}$ Eger criticized occupational counseling and assignments to vocational training done by commissions, as practiced in Bohemia and other crown lands, as unable to grasp the disabled veterans' individual circumstances and unable to control whether the given advice had been taken.

Grass-roots disabled veteran welfare and occupational counseling were supposed to overcome all these obstacles. For "only an [occupational counseling] in confidence ["vertrau-lich" [sic]] could be ${ }^{69}$ successful. The fact that members of the local boards were socially embedded in local circumstances guaranteed trustful relationships with disabled soldiers, because "it is only in his fellows from home a veteran trusts «. ${ }^{70}$ Members of the local boards would offer lowthreshold communication; with them, disabled veterans could talk in their "vernacular", their "natural way of speech «. ${ }^{71}$ Eger evoked a community initially built on the difference between a socially distanced and abstracting bureaucracy and locally embedded actors, but displaying, as shown in detail later, a national dimension as well. For Eger, the disabled veterans' trust did not stem from expert knowledge, but from socially framing this expertise. Socially embedded members of local boards would evoke trust and could thus guarantee the efficacy of expert knowledge applied ostentatiously professional institutions like committees were supposedly burdened by the problem of "the disabled soldier's mistrust against anything at all going by the name of committee «. ${ }^{72}$

Local boards in court circuits of the military command's territory were supposed to be the smallest organizational unit of this grass-roots disabled veteran welfare, consisting of a chairman, a secretary/occupational counselor and a treasurer. ${ }^{73}$ Despite Eger criticizing the organizing logic of the Landeskommissionen, both were supposed to serve as an interface between voluntary staff, charitable societies, enterprises and representatives of municipal, provincial, federal and military administration. Besides, the individual boards in the municipalities of a court circuit were supposed to appoint the so-called »trusted guardians « (Vertrauensmänner) ${ }^{74}$ to supervise smaller groups of disabled veterans and support them in their everyday life even after their successful placement in a job. ${ }^{75}$

In his preamble to Reichenberg textile manufacturer Otto Goltz' brochure „Guardianship for disabled veterans« (Die Pflegschaft für Kriegsbeschädigte), Karl Eger stressed the importance of trust once again: "It is most essential for disabled soldiers to gain trust in their guardian. «. ${ }^{76}$ These strusted guardians» were supposed to create a room for conversation, with »the invalid revealing his inner life without awkwardness, and enabling and allowing the exertion of influence. «77 This was supposed to be the only way for the strusted guardians to perform their tasks of averting "antisocial influences« on disabled veterans, discouragement due to problems resulting from the war injury or ailment and a loss of the joy of working. ${ }^{78}$ Psychologizing the challenges of re-integrative measures changed job specifications for local disabled veteran welfare staff. Not only did they need accurate knowledge about the legal framework, regulations and local economic circumstances but they also had to be able to empathize and perform "emotional labor " to control the counseling situation according to contemporary ideas of re-integration. ${ }^{79}$

Apart from organizing the interaction with disabled veterans differently, internal processes were supposed to change too. Written communication was to be replaced partly by verbal or personal communication 
and to be accelerated to some extent. Eger made a point of handling everything the local boards brought up to him "immediately and promptly «.80 An acceleration of written correspondence and personal contact between the actors was supposed to minimize the spatial distance between individual local boards and between them and the military command. This served to support the motivation of voluntary members at the local boards; beyond that, Eger intended to use meetings and gatherings to "create and maintain [an] awareness of affiliation $\ll .81$

\section{Implementation}

On 26 June 1916, the >Ortsausschuss Haida der Staatlichen Landeszentrale für das Königreich Böhmen zur Fürsorge für heimkehrende Krieger wrote a letter to Josef Kirschner. Before the war, 24-year-old Josef Kirschner had lived in Arnsdorf/Arnultovice near Haida/Nový Bor. On 2 June 1916, he had arrived in Brüx/ Most as part of an exchange of war prisoners. Now a disabled veteran, he was staying at the local military hospital when he received the letter of the local board. The social embeddedness of the local board's members was supposed to come into effect at this point of making contact to ensure a low-threshold communication with the disabled veteran. Eger deliberately refrained from instructing disabled soldiers to get in touch with local boards but tasked these boards to contact the veterans instead. The way the local board Haida/Nový Bor perceived and tried to meet the task of social reintegration concerning Josef Kirschner therefore provides insights into the ways, in which local actors implemented these normative ideas of social embeddedness.

The local board Haida/Nový Bor informed Josef Kirschner in circumlocutionary language that the military command's official for disabled veterans welfare had provided the information that one of the invalids of the exchange in Brüx/Most was "your own person, Mr. Josef Kirschner «, and "the command requested to reach a direct understanding with the very same for the purpose of an occupational counseling. ${ }^{82}$ [or alternatively, counseling “. ${ }^{82}$ ] A questionnaire was his name, rank, military unit and date of birth, among others. Crucial information for re-integrative measures concerned the job. Apart from asking about his civilian trade, the questionnaire also posed the question whether this job could be taken up again or whether the disabled veteran was already back in employment. Despite Eger's criticism of bureaucracy, administrative techniques of collecting, processing and recording data were vital elements for the network of local welfare boards. Eger explained to officials at the Ministry of Social Welfare that he initiated an "advanced card index, administered in a business-like way ${ }^{83}$ at the military command to manage the files for disabled veterans of the military command's territory. For this, Eger transformed individual cases into abstracted files with index numbers and a basic distinction between cases »taken care of «, and those still in need of medical treatment, training or employment services. Thus, Eger turned the military command into an administrative center for the local boards, which collected data and provided advice. ${ }^{84}$

Kirschner's information from the questionnaire left some room for interpretation and manoeuvre for the board. As Kirschner stated in the questionnaire, he was a skilled gilder, but before the war he had worked as a senior construction worker and substitute guard at the railroad maintenance section in Böhmisch-Leipa/Česká Lípa. In the questionnaire, he did not consider himself able to carry out his former job anymore, without clarifying whether he referred to his trade as a gilder or to his job at the railroad maintenance section. Besides, Kirschner stated not to be able to decide the kind of new trade he should pick up. ${ }^{85}$ The medical expert opinion of the district physician was vague in that regard as well; he attested to Kirschner that he was 50\% incapacitated for work with a prospect of recovery, but his remaining earning capacity was supposed to be limited to sedentary work. ${ }^{86}$ This ambiguity could have initiated an occupational counseling, as it had been stated as the purpose of the letter by the local board. If it ever came to pass, it has not been recorded, however.

The local board did not justify its further measures with referencing Kirschner's requests, but with invoking the military command Leitmeritz/Litoměřice. From the given options when determining Kirschner's former trade, the local board opted for his most recent 
employment and contacted the management of the railroad maintenance section Böhmisch-Leipa/Česká Lípa, part of the public Bohemian Northern Railway. Early in 1915, the railway ministry had guaranteed employment for disabled veteran railroad staff. ${ }^{87}$ The board's secretary did not mention this at all when requesting a statement about Kirschner from the railroad maintenance section, but the section management immediately pointed out in its written response that the decree would not be applicable in this case, because Kirschner had been enlisted to military service in 1913 and thus had not been employed by the railway at the start of the war. The decree, however, only applied to disabled soldiers employed by the railroad at the start of the war. The board's chairman and secretary then turned to the Bohemian Northern Railway's board in Prague and effected Kirschner's admission to the railway ministry's sanatorium. Besides, the railway board announced it would employ Kirschner at the railroads after his medical treatment was completed. For the local board, the determining factor did not turn out to be Kirschner's vague thoughts about a career change, but the opportunity to get him a regular employment in his most recent profession. ${ }^{88}$

The written communication of the local board Haida/ Nový Bor did not emphasize its social embeddedness but stressed its bureaucratic authority instead. When Josef Kirschner was informed about the questionnaire, the language used was in no way closer to his everyday life, as required by Eger:

\section{Enclosed can be found a directory of miscellaneous information for you to kindly and immediately send back in completed form. Awaiting the immediate execution of the return, signed, [...] the chairman. ${ }^{89}$}

The use of prevalent administrative phrases was seemingly supposed to convey the local board's official standing by creating a linguistic distinction from everyday speech..$^{90}$ While Eger considered the social embeddedness of local committees a crucial dimension of re-integrative measures by making them particularly trustful, written correspondence of the local board Haida/Nový Bor seems to hint at the fact that local actors were, in contrast, anxious to render their functions as something official. As volunteers, the local board's members stood outside of established administrative structures and, much like the Landeskommissionen, possessed no clearly defined authority. ${ }^{91}$ Instead, they were dependent on their official counterparts' willingness to cooperate. The letterhead, prominently displaying the full designation ,Local board Haida of the Provincial Commission for the Kingdom Bohemia for welfare of homecoming warriors`, was one way to emphasize the official quality of the board's function. Repeatedly referencing the military command was another. Considering the letters as a performance of administrative authority, the deliberately formal language appears to be another aspect of those efforts. Despite repeated criticism from within the administration, the circumlocutionary language used by the local board shows how a sbureaucratic style was emulated in an attempt to stress its official role..$^{92}$ Just as Eger considered the grass-roots actors' social embeddedness and accessibility beneficial and even necessary for successful re-integrative measures, local actors in Haida/Nový Bor were anxious to stage themselves not only as a private club but also as part of state administration.

\section{Trust and National Belonging}

While local actors in Haida/Nový Bor referenced both military command and Landeszentrale to strengthen their authority, the relationship between the two institutions was strained. What Scheure and Eger had in mind with their localized welfare via local boards was not merely an alternate organizational structure but the implementation of a different ordering principle for disabled veteran welfare, the principle of nationality.

Right from its inception, the Landeszentrale united a scientific and organizational landscape, which was already largely divided along national lines into German and Czech institutions. These ranged from public schools and universities in Prague to welfare institutions for physically disabled children. But they also relied on administrative bodies not yet subjected to such segregation, like the Prague accident insurance institution or the provincial central employment office.

The relationship between Landeszentrale and charitable societies for disabled soldiers in the Northern 
Bohemian territories was tension filled from the outset. In Leitmeritz/Litoměřice, Maria Zanantoni, wife of high-ranking officer Eduard Zanantoni, founded the 'Invalidenfürsorge für Leitmeritz، in October 1914 to financially support disabled soldiers. ${ }^{93}$ In Reichenberg/ Liberec, several German nationalist societies rededicated an institution established originally as an asylum for physically disabled children in 1914 as 'German-Bohemian welfare center for war cripples، (Deutschböhmische Fürsorgestelle für Kriegskrüppel und Kriegsverletzte). According to their conception, the institution had a »decidedly exclusive purpose for Germans in Bohemia «. ${ }^{94}$ While the Minister of the Interior Heinold and Franz von Thun Hohenstein, governor of Bohemia, were still negotiating establishing and staffing the Landeszentrale, Thun-Hohenstein wrote quite bluntly to Heinold that

\section{if the action formed from national-political considerations in German Bohemia indeed organized in a sober way, [...] I'd intend to appoint representatives of this organization to the Landesstelle (Provincial center), too, to form some kind of connection and collaboration..$^{95}$}

Such a cooperation happened eventually, but remained fragile. Conveying information about treatments and trainings proved to be a particular root for conflict between Landeszentrale and military command Leitmeritz/Litoměřice. ${ }^{96}$ For the Landeszentrale, the occupational counseling committees staffed with its own members were considered the only qualified boards for allocating invalids to vocational training. The fact that the military command Leitmeritz/Litoměřice and civil society actors working for disabled veteran welfare like the Reichenberg chamber of commerce failed to send the appropriate documents to the Landeszentrale or only did so belatedly was criticized by Robert Marschner in September 1917 and considered a deliberate exclusion of the Landeszentrale from implementing re-integrative measures in the military command's administrative district and contradicted decrees and edicts of the ministries of war and the interior. ${ }^{97}$

Karl Eger was therefore neither the only actor pursuing a disabled veteran welfare not depending on the Landeszentrale nor was he the only one striving for nationality as a principle for arranging veteran welfare. However, Eger proved to be an influential actor due to his institutional position as an official at the military command and his organizational skills when establishing local boards. After long negotiations between Scheure and Marschner, an agreement was reached: the Landeszentrale acknowledged the local boards on the condition that they designated themselves as local boards of the Landeszentrale. However, until the end of 1917, the military command Leitmeritz/Litoměřice remained the local boards' center of reference. ${ }^{98}$ The choice of administrative unit for the local boards illustrates that attempts at nationalizing were an inherent part of their creation. Eger argued for court circuits as basic administrative units because they would "still [be] most homogenous concerning language ${ }^{99}$ The community Eger was evoking as a foundation of the disabled veterans' personal trust not only was the community of neighbors or a village but also was tied to the larger national community of Germans in Bohemia.

This interdependence of language, national affiliation and territory arose in the second half of the 19th century. In Bohemia, cartographic representations gained particular significance as a means of nationalpolitical agitation during the preparation of a GermanCzech compromise in Bohemia from the 1890s onwards, when politicians and nationalist societies started to utilize the results of official censuses and other statistical information for graphically displaying the distribution of German and Czech nationalities in Bohemia. For this, nationalist actors adopted the official categories of the census - colloquial or preferred language interpreted them as national affiliation and transferred them to the so-called language or nationality maps. ${ }^{100}$ Depending on the territorial unit, linguistic minorities and majorities shifted and defining a threshold value for indicating a linguistic minority by colour led to the disappearance of multilingualism in whole regions. ${ }^{101}$ Consequentially, "mixed-language areas were willingly shown as nationally homogenous spaces of the majority population in a generalized way or at least perceived as such by viewers. «102 The sources do not indicate whether and to what extent the local boards were nationally homogenous associations themselves. While in Eger's eyes, this assumed homogeneity of administrative areas 
enabled personal relationships based on trust in national ,fellows at home (Heimatgenossen); analytically, such trust cannot be presupposed. Rather, a disabled veteran welfare performed via personal contact primarily by members of one nation can be assumed to induce and strengthen such nationalized feelings. After all, starting in the late 19th century, nationalist associations had already begun to use social welfare as a means of nationalizing the population of Bohemia. ${ }^{103}$

However, Eger did not restrict himself to making those administrative units, which he considered homogenous, the foundation of disabled veteran welfare; he proactively tried to establish such a homogeneity. Until 1917, the Landeszentrale's occupational counseling commissions called on disabled soldiers in military hospitals. Starting 1 May 1917, a collection point was established in Kolin/Kolín, where a commission of strusted experts` (Vertrauensmänner) from the Landeszentrale regularly examined the disabled soldiers of the military command Leitmeritz/ Litoměřice territory to allocate them to vocational training courses. As a reaction to this, in August 1917, the chamber of commerce in Reichenberg/Liberec requested that the military command should establish another collection point there. Although Ferdinand Breinl, the chamber's chairman, was a trusted expert of the Ministry of Public Works for German-speaking trade schools offering disabled veteran training, Eger and another military command official interpreted Breinl's request as an attempt to introduce national segregation to disabled veteran welfare by presenting Czech-speaking veterans to the committee in Kolin/ Kolín and German-speaking veterans in Reichenberg/ Liberec. In his written response, the official stated that this "could not be approved of by the military command, [...] because politics of all manners had to be kept off the treatment of disabled veterans «. ${ }^{104}$ Eger added an (diametrically opposite) assessment of his own and stated:

This request [to establish two collection points] has already been made by the undersigned official [i.e. Eger], taking into account the given national circumstances in our military command's territory, when the collection point was established in Kolin. ${ }^{105}$
Actually, at the meeting between representatives of the provincial commissions (Landeskommissionen) and ministries in Vienna in May 1917, Eger had already demanded to establish a disabled veteran department (Invalidenamt) in Bohemia, modelled after the Transleithanian part of the Empire, but divided into a German and a Czech section. He would do so again when called to the Ministry of Social Welfare in January 1918. ${ }^{106}$

This undertaking was not devoid of national stereotypes. Eugen von Scheure, talking about fellow citizens who enticed disabled soldiers to live on veteran pension instead of an employment, put the following words in their mouth: "'What do you [the veteran] need to work for? Franta did this to you, Franta should care for you!« Utilizing the Czech diminutive for František, which was, as Scheure explicitly mentioned himself, a »designation for Francis Joseph I« widely used, he implied that a disinclination to work, connected in the contemporary manner with an insistence on pension, was a Czech quality ${ }^{107}$ Eger, however, did probably not intend to put Czech-speaking disabled veterans in a worse position than German-speaking ones; he rather sought to achieve national segregation in welfare. In collaboration with local actors, he established the Eastern Bohemian welfare center for disabled veterans (Ostböhmische Fürsorgestelle für Kriegsbeschädigte) in Königgrätz/ Hradec Králové, ${ }^{108}$ possibly intended as a contact point primarily for Czech-speaking disabled veterans in the military command's territory. ${ }^{109}$ Segregation was achieved in November 1917 when the Landeszentrale approved of establishing a second collection point in Reichenberg/ Liberec and dividing disabled veterans along national lines between Kolin/Kolín and Reichenberg/Liberec and later Teplitz-Schönau/Teplice-Šanov as well. ${ }^{110}$

But this did not satisfy local actors. In February 1918, Robert Marschner requested support from the Ministry of Social Welfare. In August 1917, he and Karl Eger had agreed upon the Landeszentrale taking over the local boards. Those boards' representatives - "all of them citizens of German districts only «, ${ }^{111}$ as Marschner noted - gave an ultimatum to the Landeszentrale, rendering this takeover void if the administrative segregation of the Bohemian disabled veteran welfare would not be implemented within six months. The Ministry of Social Welfare postponed resolving this matter until 
meeting with the Bohemian governor. ${ }^{112}$ This again demonstrated the room for manoeuvre local actors held to advance the segregation of disabled veteran welfare.

\section{Conclusion}

Grass-roots disabled veteran welfare based on socially embedded volunteers and trusted guardians was no project put forward exclusively by Karl Eger. Simultaneously and initially unbeknownst to each other, Rudolf Peerz publicized a similar administrative organization. Peerz worked as a war correspondent and propagator for the Ministry of War and, in 1916, was transferred to the Ministry of the Interior as an official propagator for local disabled veteran welfare boards in Upper Austria, Salzburg and Styria. Peerz, who seemed to have combined his roles as a war correspondent and welfare propagator in his numerous talks, proved to be much less successful at organizing than Eger. ${ }^{113}$ Nonetheless, the simultaneous emergence of such projects shows how the challenges of disabled veteran welfare fostered a re-evaluation of bureaucratic practices, revolving around social embeddedness and trust. As political elites strove to project a positive image of how the monarchy was handling the war and its social repercussions, social policy took center stage in such efforts. The main propagators of such alternate administrative structures were not ministry officials, but actors on the margins of civil service; Eger had been an elementary school teacher before the war, and Peerz held the title of a professor. ${ }^{114}$ As the monarchy was dependent on civil society actors to sustain its welfare efforts, they enjoyed considerable leeway in putting welfare measures into effect. While historiography has mostly focused on the repressive elements of wartime bureaucracy, the issue of trust shows how imperial elites, and also nationalist activists, tried to use administrative structures to foster and sustain different feelings of social belonging. Whether there were attempts similar to Eger's at making welfare administration a tool for nationalizing Bohemia's population in other multilingual crown lands, such as Styria or Carinthia, where similar processes of national segregation had happened before 1914, requires further research. ${ }^{115}$
The concept of trust, however, also points beyond the war. The issue of trust in administrative settings shows how bureaucratic norms of social distance and detachment had to be negotiated in response to historically specific challenges and expectations about the behavior of administrative officials which made inducing emotional connections between citizenry and administration seem imperative. Pre-war debates about administrative reform already intertwined the issue of trust with the monarchy's administrative reach and a change in attitudes and practices of officials. This trust discourse also influenced the social welfare reform of 1917/1918 and the social welfare structures of the monarchy's successor states. ${ }^{116}$ Emperor Charles I reacted to the waning of social cohesion caused by mobilizing the population for war, the supply crisis, and impoverishment with attempts to reinvigorate personal loyalty towards the emperor. At the same time, he sought to strengthen the monarchy's administrative reach via a comprehensive welfare policy. ${ }^{117}$ Trust again emerged as an issue in the reform plans of ministerial officials in the newly established Ministry of Social Welfare. When, for example, in a ministry discussion, the director of the Upper Austrian Employment Service attributed his institution's failure to the assumed "inferior moral qualities" of disabled veterans, division chief Otto Gasteiger replied asking whether the fact that the occupational counselors held "too little of the disabled veterans' trust « would not offer a better explanation instead. ${ }^{118}$ Therefore, building trust was one purpose of the administrative reform, which was intended to establish a federal administrative structure reaching from the Viennese headquarters to the regional committees, disabled veteran departments/ local centers and eventually to the trusted guardians and thus individual disabled veterans. ${ }^{119}$

Ministry officials considered the social embeddedness of the welfare administration an important factor for the success of re-integrative action as well, but they shifted the vectors of this social embeddedness at one crucial point. While disabled soldiers had been acknowledged as actors of re-integrative measures thus far only when demonstrating prostheses, supervising or assisting in disabled veteran training, they were now supposed to be employed as officials of the welfare administration's first-line authorities. ${ }^{120}$ Even though these attempts 
$\begin{array}{lllllllllllllllll}\text { A } & D & \text { III } & \text { I } & \text { N } & \text { I } & \text { S } & \text { T } & 0 & R & Y & 3 & / & 2 & 0 & 1 & 8\end{array}$

to reform failed to prevent the Habsburg Monarchy's disintegration, Austria as well as Czechoslovakia pursued this concept and included disabled veterans in their post-1918 welfare administrations. In an attempt to balance social embeddedness and social detachment, disabled veterans were usually employed in a service capacity in local branches, while provincial commissions determined social welfare claims. ${ }^{121}$

Translated by Simone Heller 
1 ÖStA (Österreichisches Staatsarchiv [Wien]), AVA (Allgemeines Verwaltungsarchiv), MdI (Ministerium des Inneren), Praes., 19, Kt. 1862, 19093/1914 Bekämpfung der Kriegsschäden für die Angehörigen der Wehrmacht und ihre Familien. /: Militärversorgungsgesetze und Anregung einer präventiven Hilfsaktion:/ pp. 5-8, at p.1.

2 ÖStA, AVA, MdI, Praes., 19, Kt. 1862, 19093/1914 Bekämpfung der Kriegsschäden für die Angehörigen der Wehrmacht und ihre Familien. /: Militärversorgungsgesetze und Anregung einer präventiven Hilfsaktion:/ p. 1-8, here: p. 1.

3 ÖStA, AVA, MdI, Praes., 19, Kt. 1862, 19093/1914 Bekämpfung der Kriegsschäden für die Angehörigen der Wehrmacht und ihre Familien. I: Militärversorgungsgesetze und Anregung einer präventiven Hilfsaktion :/, 2. Bogen.

4 ÖStA, AVA, MdI, Praes., 19, Kt. 1862, 3501/1915, Maßnahmen zur Wiederherstellung der Arbeitsfähigkeit der Kriegs-Invaliden, Bildung von Landeskommissionen.

5 Ke-chin Hsia: „Who Provided Care for Wounded and Disabled Soldiers? Conceptualizing State-Civil Society Relationship in First World War Austria«, in: Joachim Bürgschwentner / Matthias Egger / Gunda Barth-Scalmani (eds.): Other Fronts, Other Wars? First World War Studies on the Eve of the Centennial, Leiden 2014, pp. 303-328.

6 Patrick Joyce: The State of Freedom. A Social History of the British State since 1800, Cambridge 2013, p. 19.

7 Stefan Nellen / Thomas Stockinger: "Staat, Verwaltung und Raum im langen 19. Jahrhundert. Einleitung«, in: Administory 2 (2017), pp. 3-34, at p.9.

8 Hsia: Care, pp. 303-306.

9 Mark Cornwall: »Disintegration and Defeat. The Austro-Hungarian Revolution«, in: Mark Cornwall (ed.): The Last Years of AustriaHungary. A Multi-National Experiment in Early Twentieth-Century Europe, Exeter 2002, pp. 167-196, at p. 171.

10 Maureen Healy: Vienna and the Fall of the Habsburg Empire. Total War and Everyday Life in World War I, Cambridge 2004, p. 1-86; Alfred Pfoser / Andreas Weigl: "Die Pflicht zu sterben und das Recht zu leben. Der Erste Weltkrieg als bleibendes Trauma in der Geschichte Wiens", in: Alfred Pfoser / Andreas Weigl (eds.): Im Epizentrum des Zusammenbruchs. Wien im Ersten Weltkrieg, Wien 2013, pp. 14-31, here p. 23-29; Christian Mertens: "Die Wiener Stadtverwaltung im Ersten Weltkrieg«, in: Pfoser / Weigl: Epizentrum, pp. 284-291; Manuela Hauptmann: Unterhaltsbeiträge für Soldatenfamilien der Habsburgermonarchie im Ersten Weltkrieg, Diss. Universität Wien 2015, pp. 151-154, pp. 168-189; Sabine Schmitner: "Local politics during the First World War. Political players in the armaments center Wiener Neustadt«, in: European Review of History 24 (2017), pp. 229-249.

11 Anton Holzer: Die andere Front. Fotografie und Propaganda im Ersten Weltkrieg mit unveröffentlichten Originalaufnahmen aus dem Bildarchiv der Österreichischen Nationalbibliothek, Darmstadt 2007; Peter Becker: »Recht, Staat und Krieg. ,Verwirklichte Unwahrscheinlichkeiten Administory 1 (2016), pp. 28-53; Julie Thorpe: „Displacing Empire: Refugee Welfare, National Activism and State Legitimacy in AustriaHungary in the First World War«, in: Panikos Panayi / Pippa Virdee (eds.): Refugees and the End of Empire. Imperial Collapse and Forced Migration in the Twentieth Century, Basingstoke 2001, pp. 102-126; Rebekah Klein-Pejšová: „Beyond the IInfamous Concentration Camps of the Old Monarchy،. Jewish Refugee Policy from Wartime Austria-Hungary to Interwar Czechoslovakia«, in: Austrian History Yearbook 45 (2014), pp. 150-166.

12 Didier Fassin: »Introduction. Governing Precarity«, in: Didier Fassin et al.: At the Heart of the State. The Moral World of Institutions.
Anthropology, Culture and Society, London 2015, pp. 1-11; Didier Fassin: „Conclusion. Raisons d'État«, in: Didier Fassin et al.: At the Heart of the State. The Moral World of Institutions. Anthropology, Culture and Society, London 2015, pp. 255-261.

13 Peter Becker / Rüdiger von Krosigk: "Introduction. New Perspectives on the History of Bureaucratic and Scientific Subjects", in: Peter Becker / Rüdiger von Krosigk (eds.): Figures of Authority. Contributions towards a Cultural History of Governance from the Seventeenth to the Twentieth Century, Brüssel 2008, pp. 11-26, at p. 21.

14 Becker / Krosigk: "Introduction«, pp. 19-21; Peter Becker: »Formulare als `Fließband der Verwaltung? Zur Rationalisierung und Standardisierung von Kommunikationsbeziehungen«, in: Peter Collin / Klaus-Gert Lutterbeck (eds.): Eine intelligente Maschine? Handlungsorientierungen moderner Verwaltung (19./20. Jh.), Baden-Baden 2009, pp. 291-308.

15 Gary B. Cohen: "Neither Absolutism nor Anarchy. New Narratives on Society and Government in Late Imperial Austria«, in: Austrian History Yearbook 29 (1998), pp. 37-61; Gary B. Cohen: »Nationalist Politics and the Dynamics of State and Civil Society in the Habsburg Monarchy 1867-1914«, in: Central European History 40 (2007), p. 242-278; Pieter M. Judson: The Habsburg Empire. A new History, Cambridge, MA 2016, pp. 333-384.

16 See for an in-depth discussion of this narrative: John Deak: »The Great War and the Forgotten Realm: The Habsburg Monarchy and the First World War«, in: The Journal of Modern History 86 (2014), pp. 336-380.

17 Laurence Cole: Military Culture and Popular Patriotism in Late Imperial Austria, Oxford 2014; Daniel Unowsky: The Pomp and Politics of Patriotism. Imperial Celebrations in Habsburg Austria, 1848-1916, Purdue University Press 2005.

18 Healy: Vienna, pp. 258-299.

19 Ute Frevert: Vertrauensfragen. Eine Obsession der Moderne, München 2013, pp. 28-37, 147-179.

20 Jakob Tanner: »'Die Währung der Finanzmärkte ist Vertrauen<. Nachhaltigkeit und Hinterhältigkeit eines mentalen Phänomens in historischer Perspektive«, in: Jörg Barberowski (ed.): Was ist Vertrauen? Ein interdisziplinäres Gespräch, Frankfurt am Main / New York 2014, pp. 73-100, esp. p. 99. Tanner draws on: Ernesto Laclau / Chantal Mouffe: Hegemony and Socialist Strategy. Towards a Radical Demoncratic Politics, London / New York 2014 (1985).

21 Ute Frevert: "Vertrauen. Historische Annäherungen an eine Gefühlshaltung«, in: Claudia Benthien / Anne Fleig / Ingrid Kasten (eds.): Emotionalität. Zur Geschichte der Gefühle, Köln 2000, pp. 178-197, at p. 193.

22 For Koerber's studies and the work of the committee, see John Deak: Forging a Multinational State. State Making in Imperial Austria from the Enlightenment to the First World War, Stanford, California 2015, pp. 237-258; Peter Becker: "'... dem Bürger die Verfolgung seiner Anliegen erleichtern<. Zur Geschichte der Verwaltungsreform im Österreich des 20. Jahrhunderts«, in: Heinrich Berger et.al. (ed.): Politische Gewalt und Machtausübung im 20. Jahrhundert. Zeitgeschichte, Zeitgeschehen und Kontroversen, Festschrift für Gerhard Botz, Wien 2011, pp. 113-138, at pp. 113-121.

23 Deak: State, p. 235.

24 Ernest von Koerber: Studien über die Reform der inneren Verwaltung, Wien 1904, p. 8.

25 Koerber: Studien, p. 4.

26 Koerber: Studien, pp. 8, 24-28; Deak: State, p. 256.

27 Barbara H. Rosenwein: "Problems and Methods in the History of Emotions«, in: Passions in Context 1.1 (2010), pp. 1-32; Martin 
Endreß argues against conceiving of trust only as an emotion: Martin Endreß: Vertrauen, Bielefeld 2002, p. 70; Eric M. Uslaner defines trust as a moral value: Eric M. Uslaner: The Moral Foundations of Trust, Cambridge 2002, pp. 14-50.

28 Stefan Haas: Verwaltungsgeschichte nach Culturalund Communicative Turn. Perspektiven einer historischen Implementationsforschung", in: Stefan Brakensiek / Corinna von Bredow / Birgit Näther (eds.): Herrschaft und Verwaltung in der Frühen Neuzeit, Berlin 2014, pp. 181194; André Holenstein: "Introduction. Empowering Interactions. Looking at Statebuilding from Below«, in: André Holenstein et al. (ed.): Empowering Interactions. Political Cultures and the Emergence of the State in Europe 1300-1900, Farnham 2009, pp. 1-31; Mary Douglas / Steven Ney: Missing Person. A Critique of Personhood in the Social Sciences, Berkeley / Los Angeles 1998; Lorraine Daston / H. Otto Sibum: "Introduction. Scientific Personae and Their Histories«, in: Science in Context 16 (2003), pp. 1-8; Becker / Krosigk: »Introduction«, pp. 11-26.

29 Verena Pawlowsky / Harald Wendelin: Die Wunden des Staates. Kriegsopfer und Sozialstaat in Österreich 1914-1938, Wien 2015, pp. 93-102.

30 ÖStA, AVA, MdI, Praes. 19, Kt. 1862, 2663/1915, »Invalidenfond» [sic], Sammeltätigkeit; Hsia: Care.

31 Pawlowsky / Wendelin: Wunden, pp. 102-107.

32 VúA (Vojenský ústřední archiv [Praha]), VHA (Vojenský historický archiv), KK9 (9. Korpskommando), Praes., 1451/1916, Kriegsfürsorgefond [sic] der Truppenkörper.

33 ÖStA, AVA, MdI, Praes. 19, Kt. 1862, 1706/1915 Aktion zu Gunsten der aus dem Kriege als bleibend invalid zurückkehrenden Soldaten; ebd., 3815/1915 Kriegsblindenfürsorge.

34 ÖStA, AVA, MdI, Praes. 19, Kt. 1862, 5425/1915, Fürsorgeaktion für heimkehrende Krieger. Hinausgabe grundsätzlicher Vorschriften und einer Geschäftsordnung für die Landeskommissionen; N.d.: Bericht über die Tätigkeit der Staatlichen Landeszentrale für das Königreich Böhmen zur Fürsorge für heimkehrende Krieger im Jahr 1915, n.p. n.y., pp. 4-5.

35 N.d.: Bericht, pp. 12-13.

36 N.d.: První Zpráva o činnosti Spolku pro léčbu a výchovu mrzáků, Jedličkova ústavu pro zmrzačelé a školy pro vojíny-invalidy v Praze v letech 1913-1917 [First Activity Report of the Association for the Care and Education of Cripples, of the Jedlička-Institute for the Crippled and the School for War Invalids in Prague 1913-1917], Prag 1915, pp. 36-42; n.d., Die Deutschböhmische Fürsorgestelle für Kriegskrüppel und Kriegsverletzte mit dem Sitze in Reichenberg. Ein Rechenschaftsbericht, Reichenberg 1916, pp. 5-8.

37 N.d.: Bericht, pp. 3-4.

38 See for example: NAP (Národní archiv [Praha]), MVP-R (Ministerstvo veřejných prací - Rakousko), Kt. 1043, 37628/1916 Periodischer Bericht in Angelegenheit der Invalidenschulen.

39 Richard Sudek: »Arbeitsvermittlung an Kriegsinvalide», in: Österreichische Rundschau 45 (Oktober-Dezember 1915), pp. 4955, at p. 52.

40 N.d.: Bericht, p. 29.

41 Anthony Giddens: The Consequences of Modernity, Cambridge 1991 [1990], p. 83-92.

42 Pawlowsky / Wendelin: Wunden, pp. 139-146.

43 Emerich Ferenczi: Die Wiedereingliederung der Kriegsinvaliden ins bürgerliche Erwerbsleben in Deutschland, Österreich und Ungarn, Wien / Leipzig 1916, p. 7.

44 Ferenczi: Wiedereingliederung, p. 8.

45 Ferenczi: Wiedereingliederung, pp. 7-8; Otto Burkard: „Über die Schulung Kriegsinvalider«, in: Mitteilungen des k. k. Ministeriums des Innern über Fürsorge für Kriegsbeschädigte 9 (März 1916), pp. 99-105; Jan Dvořák: Několik pokynů těžce raněným vojínům/ Einige Winke für schwerverwundete Soldaten, Praha n.y., unnumbered, appealing to the trust of the invalids.

46 Pawlowsky / Wendelin: Wunden, pp. 117-123; Hans Spitzy: "Geleitwort", in: Adolf Deutsch: Ärztliche Berufsberatung Kriegsbeschädigter im Rahmen der Arbeitsvermittlung, Wien 1917, p. 5.

47 Gernot Böhme: »Trau, schau, wem!«, in: Die Zeit 52 (16.12.1998), p. 45, cited in: Ute Frevert: »Über Vertrauen reden. Historisch-kritische Betrachtungen«, in: Barberowski: Vertrauen, pp. 31-48, at p. 38.

48 Giddens: Consequences, pp. 85-86.

49 Josef Pokorny: "Über Berufsberatung von Kriegsbeschädigten«, in: Wiener Medizinische Wochenschrift 66.18 (1916), pp. 687-692, at p. 688.

50 Deutsch: Berufsberatung, p. 32.

51 Deutsch: Berufsberatung, p. 32.

52 Deutsch: Berufsberatung, p. 29.

53 Deutsch: Berufsberatung, pp. 27-28.

54 Monique Scheer: »Are Emotions a Kind of Practice (and Is That What Makes Them Have a History)? A Bourdieuan Approach to Understanding Emotion«, in: History and Theory 51 (2012), p. 193220, here p. 209-217.

55 Arlie Russell Hochschild: Das gekaufte Herz. Zur Kommerzialisierung der Gefühle, übersetzt von Ernst von Kardorff, Frankfurt am Main 1990 , p. 53, pp. 120-125.

56 Deutsch: Berufsberatung, p. 27.

57 Referent für Invalidenfürsorge beim k.u.k. Militärkommando Leitmeritz (ed.): Handbuch für die Berufsberater der Kriegsbeschädigten, Leitmeritz 1916.

58 VÚA, VHA, KK9, MA Kt. 220, MA 55-22/90-5 (10.3.1917) Arbeitsvermittlung an Kriegsinvalide.

59 K. u. k. Militärkommando in Leitmeritz (Kriegsbeschädigtenfürsorge): An unsere verwundeten und kranken Krieger!, Leitmeritz 1916, in: SOA Liberec (Státní Okresní Archiv [Liberec]), AML-W, Kt. 113, 106; VÚA, VHA, KK9, MA Kt. 221, 55-29/7 (2.9.1916), Flugschrift „Die Beratung der Kriegsbeschädigten«, Versendung; VÚA, VHA, KK9, MA 55-29/5.

60 Referent: Handbuch, p. 37-44.

61 N.d.: "Sitzungsbericht der Versammlung der Vertreter der Landeskommissionen zur Fürsorge für heimkehrende Krieger am 18.5.1917 «, in: Mitteilungen des k. k. Ministeriums des Innern über Fürsorge für Kriegsbeschädigte 23/24 (Mai/Juni 1917), pp. 261-299, at pp. 278-282.

62 For the plan of a social welfare administrative reform, see Ke-chin Hsia: War, Welfare and Social Citizenship. The Politics of War Victim Welfare in Austria, 1914-1925, Diss. University of Chicago 2013, pp. 129-193; Pawlowsky / Wendelin: Wunden, p. 176f, p. 185.

63 ÖStA, KA (Kriegsarchiv), KM (Kriegsminsterium), Abt. 9/IF, Kt. 1417, 434/1917, Organisation der Kriegsbeschädigtenfürsorge, unnumbered.

64 ÖStA, KA, KM, Abt. 9/IF, Kt. 1417, 434/1917, Organisation der Kriegsbeschädigtenfürsorge, unnumbered.

65 ÖStA, KA, KM, Abt. 9/IF, Kt. 1417, 434/1917, Organisation der Kriegsbeschädigtenfürsorge, unnumbered.

66 See for the intense educational work in the German Empire: Heather R. Perry: Recycling the Disabled. Army, Medicine, and Modernity in WWI Germany, Manchester 2014, pp. 118-129.

67 N.d.: Sitzungsbericht, p. 279.

68 N.d.: Sitzungsbericht, p. 278.

69 N.d.: Sitzungsbericht, p. 278. 
70 N.d.: Sitzungsbericht, p. 279.

71 ÖStA, KA, KM, Abt. 9/IF, Kt. 1417434/1917, Organisation der Kriegsbeschädigtenfürsorge, unnumbered.

72 ÖStA, KA, KM, Abt. 9/IF, Kt. 1417434/1917, Organisation der Kriegsbeschädigtenfürsorge, unnumbered.

73 VÚA, VHA, KK9, Praes. 1776/1917 KM IF 216 vom 22.02.1917.

74 N.d.: Sitzungsbericht, p. 281.

75 Otto Goltz: Die Pflegschaft für Kriegsbeschädigte, Reichenberg 1917.

76 Karl Eger: untitled, in: Goltz: Pflegschaft, pp. 3-5, at p. 4.

77 Goltz: Pflegschaft, p. 9.

78 Goltz: Pflegschaft, p. 9.

79 Hochschild: Das gekaufte Herz, p. 53.

80 ÖStA, AdR (Archiv der Republik), BMfsV (Bundesministerium für soziale Verwaltung), Sek. 2/KB Kt. 1358, 3848/1918 Kriegsbeschädigtenfürsorge; Vorschlag zur Ausgestaltung, pp. 1-44, at p. 7.

81 ÖStA, AdR, BMfsV, Sek. 2/Kb Kt. 1358, 3848/1918 Kriegsbeschädigtenfürsorge; Vorschlag zur Ausgestaltung, p. 8.

82 VÚA, VHA, KK9, MA Kt. 220, MA 55-9/18-2, Josef Kirschner, L[w]IR 10 - Nachbehandlung, Ortsausschuss Haida an Josef Kirschner.

83 ÖStA, AdR, BMfsV, Sek. 2/Kb Kt. 1358, 3848/1918 Kriegsbeschädigtenfürsorge; Vorschlag zur Ausgestaltung, pp. 1-44, here p. 6.

84 ÖStA, AdR, BMfsV, Sek. 2/Kb Kt. 1358, 3848/1918 Kriegsbeschädigtenfürsorge; Vorschlag zur Ausgestaltung, pp. 6, 8-9.

85 VÚA, VHA, KK9, MA Kt. 220, MA 55-9/18-2, Josef Kirschner, L[w]IR 10 - Nachbehandlung, Ortsausschuss Haida an Josef Kirschner.

86 VÚA, VHA, KK9, MA Kt. 220, MA 55-9/18-2, Josef Kirschner, L[w]IR 10 - Nachbehandlung, Ortsausschuss Haida an Josef Kirschner.

87 N.d.: Denkschrift über die von der k. k. Regierung aus Anlass des Krieges getroffenen Massnahmen. Bis Ende Juni 1915, Wien 1915, p. 131.

88 VÚA, VHA, KK9, MA Kt. 220, MA 55-9/18-2, Josef Kirschner, L[w]IR 10 - Nachbehandlung, Ortsausschuss Haida an Josef Kirschner.

89 VÚA, VHA, KK9, MA Kt. 220, MA 55-9/18-2, Josef Kirschner, L[w]IR 10 - Nachbehandlung, Ortsausschuss Haida an Josef Kirschner.

90 Haas: Verwaltungsgeschichte.

91 Pawlowsky / Wendelin: Wunden, 189.

92 Ernst Mayrhofer: Handbuch für den politischen Verwaltungsdienst in den im Reichsrathe vertretenen Königreichen und Ländern, Bd. 1, Wien ${ }^{4} 1880$, p. 731-733; Peter Becker: «'Das größte Problem ist die Hauptwortsucht`. Zur Geschichte der Verwaltungssprache und ihrer Reformen, 1750-2000«, in: Peter Becker (ed.): Sprachvollzug im Amt. Kommunikation und Verwaltung im Europa des 19. und 20. Jahrhundert, Bielefeld 2011, pp. 219-244.

93 N.d.: Jahrbuch der Invalidenfürsorge für den Bereich des Militärkommandos Leitmeritz, Gablonz an der Neiße 1917, pp. 11-14.

94 N.d.: Fürsorgestelle, p. 12.

95 ÖStA, AVA, MdI Praes. 19, Kt. 1862, 5425/1915, Fürsorgeaktion für heimkehrende Krieger. Hinausgabe grundsätzlicher Vorschriften und einer Geschäftsordnung für die Landeskommissionen, Statthalter in Böhmen an den Innenminister.

96 N.d.: Bericht, pp. 11, 17.

97 VÚA, VHA, KK9, MA Kt. 232, MA 55-6/5-92II Vorlage der Ausweise über Schulung von Kriegsbeschädigten in Reichenberg. Ausweisleistung über Kriegsbeschädigte an die Landeszentrale überhaupt.

98 ÖStA, AdR, BMfsV, Sek. 2/Kb Kt. 1358, 5934/1918, Nationale Zweiteilung der Staatlichen Landeszentrale; ÖStA, KA, KM Kt. 1417, pp. 1-15, at pp. 7-9.

99 ÖStA, KA, KM Kt. 1417, 434/1917, Organisation der Kriegsbeschädigtenfürsorge, unnumbered.
100 Wolfgang Göderle: Zensus und Ethnizität. Zur Herstellung von Wissen über soziale Wirklichkeiten im Habsburgerreich zwischen 1848 und 1910, Göttingen 2016, pp. 63-73, 219-228; Pieter M. Judson: "Marking National Space on the Habsburg Austrian Borderlands: 1880-1918«, in: Omer Bartov / Eric D. Weitz (eds.): Shatterzone of Empires: Coexistence and Violence in the East, Central, and Southeast European Borderlands, Bloomington 2013, pp. 122-135; Gerald Stourzh: „Ethnic Attribution in Late Imperial Austria: Good Intentions, Evil Consequences«, in: Gerald Stourzh: From Vienna to Chicago and Back. Essays on Intellectual History and Political Thought in Europe and America, Chicago 2007, pp. 157-176, particularly: pp. 162-163.

101 Robert Luft: »Alte Grenzen und Kulturgeographie. Zur historischen Konstanz der Grenzen Böhmens und der böhmischen Länder «, in: Hans Lemberg (ed.): Grenzen in Ostmitteleuropa im 19. und 20. Jahrhundert. Aktuelle Forschungsprobleme, Marburg 2000, pp. 95-135, at p. 127.

102 Luft: »Grenzen«, p. 127.

103 Tara Zahra: »Each nation only cares for its own«. Empire, Nation, and Child Welfare Activism in the Bohemian Lands, 1900-1918«, in: The American Historical Review 111 (2006), pp. 1378-1402; Peter Haslinger: „Einleitung. Wen und wovor schützen Schutzvereine? Problemaufriss und Versuch einer Einordnung", in: Haslinger: Schutzvereine, pp. 7-19. Ostmitteleuropa. Vereinswesen, Sprachenkonflikte und Dynamiken nationaler Mobilisierung 18601939, Marburg 2009, pp. 7-19.

104 VÚA, VHA, KK9, MA Kt. 232, MA 55-6/5-114 (29.11.1917) Aufstellung einer Berufsberatungskommission in Reichenberg.

105 VÚA, VHA, KK9, MA Kt. 232, MA 55-18/14-21 I (19.8.1917) Nachbehandlung Kriegsbeschädigter in Reichenberg.

106 N.d.: Sitzungsbericht, p. 281; ÖStA, AdR, BMfsV, Sek. 2/KB Kt. 1358, 3848/1918 Kriegsbeschädigtenfürsorge; Vorschlag zur Ausgestaltung, pp. 1-44, at pp. 36-37; Pawlowsky / Wendelin: Wunden, p. 185.

107 VÚA, VHA, KK9, Praes., 1776/1917 KM IF 216 vom 22.2.1917.

108 VÚA, VHA, KK9, MA Kt. 235, MA 55-41/1 (11.1.1917) Errichtung einer Ostböhmischen Fürsorgestelle für Kriegsbeschädigte in Königgrätz.

109 ÖStA, KA, KM Kt. 1417, 183/1917, pp. 1-15, at pp. 10-11.

110 VÚA, VHA, KK9, MA Kt. 245, MA55-18/6-18(07.9.1918) Berufsberatung Kriegsbeschädigter durch die Vertrauensmännerkommission der Staatlichen Landeszentrale Prag, Abänderung der getroffenen Bestimmungen.

111 ÖStA, AdR, BMfsV, Sek. 2/Kb Kt. 1358, 5934/1918, 21.2.1918, Nationale Zweiteilung der Staatlichen Landeszentrale.

112 ÖStA, AdR, BMfsV, Sek. 2/Kb Kt. 1358, 5934/1918, 21.2.1918, Nationale Zweiteilung der Staatlichen Landeszentralea.

113 Pawlowsky / Wendelin, Wunden, pp. 173-175.

114 Eger: ÖStA, AdR, BMfsV Sek. 2/Kb Kt. 1356, 1808/1918 Besprechung mit dem Bureauleiter der Staatlichen Landeszentrale zur Fürsorge für heimkehrende Krieger für das Königreich Böhmen, Reg. Rat Marschner.

115 Martin Moll: Kein Burgfrieden. Der deutsch-slowenische Nationalitätenkonflikt in der Steiermark 1900-1918, Innsbruck 2007; Andreas Moritsch: »Modernisierung und nationale Differenzierung bis 1918«, in: Andreas Moritsch (ed.): Austria-Slovenica. Die Kärntner Slovenen und die Nation Österreich / Koroški Slovenci in avstrijska nacija, Klagenfurt 1996, pp. 45-57.

116 For this impact on post-war social welfare, see Hsia: War, pp. 129-258, 329-413; Natali Stegmann: Die Habsburgermonarchie als Fundament. Sozialpolitik in der Tschechoslowakei, 1918-1948, in: Kathrin Boeck et al. (eds.): Staatsbürgerschaft und Teilhabe. Bürgerliche, politische und soziale Rechte im östlichen Europa, Oldenbourg 2014, pp. 51-65. 
117 Healy: Vienna, pp. 31-86, 122-161, 258-299.

118 ÖStA AdR BMfsV, Sek. 2/Kb Kt. 1358, 4471/1918, Bericht über die am 07.2.1918 im Min.f.s.Fürsorge stattgefundene Besprechung der Büroleiter der k.k. Arbeitsvermittlungen zur Sicherstellung eines engeren Zusammenschlusses zwischen Landeskommissionen und Landesstellen der k.k. Arbeitsvermittlung an KI, pp. 1-10, at p. 3 (Upper Austria), p. 4 (Gasteiger).

119 ÖStA, AdR, BMfsV, Sek. 2/Kb Kt. 1363, 25655/1918 Erlaß des MfsF vom 05.3.1918, 6544 Ausgestaltung der Organisation der Kriegsbeschädigtenfürsorge, pp. 1-5, at pp. 1-3.

120 ÖStA, AdR, BMfsV, Sek. 2/Kb Kt. 1363, 25655/1918 Erlaß des MfsF vom 05.3.1918, 6544 Ausgestaltung der Organisation der Kriegsbeschädigtenfürsorge, p. 3; For a discussion of »model disabled veterans« see Sabine Kienitz: Beschädigte Helden. Kriegsinvalidität und Körperbilder 1914-1923, Paderborn 2008, pp. 192-209.

121 Peter Becker: "'Die kameradschaftlichste Unterstützung،. Das Invalidenamt als Ort eines neuen Verwaltungsverständnisses«, in: Sandra Maß / Xenia von Tippelskirch (eds.): Faltenwürfe der Geschichte. Entdecken, entziffern, erzählen, Frankfurt am Main 2014, pp. 179-196. 


\section{Abstract}

This contribution examines the role of trust in disabled veteran welfare in Bohemia during the First World War. It places this concern for disabled veterans' trust in a wider political context as trust emerged as a specific concern in Cisleithanian political discourses on administrative reform around 1900. In the context of welfare for disabled veterans in Cisleithania, trust gained novel importance. Medical and occupational experts deemed it imperative to gain disabled veterans' trust to maintain their role as experts and developed specific strategies of emotionally engaging with disabled soldiers to gain their trust. Karl Eger, a military official, emerged as an influential actor in Bohemian welfare for disabled veterans. He propagated a welfare administration based on local welfare boards, which would supposedly possess disabled veterans' trust. His idea of trust was, however, based on concepts of national communities and he implemented it to re-organize disabled veteran welfare based on nationality.

\section{About the Author}

Thomas Rohringer is a Ph.D. student at the Technical University Berlin. He was a doctoral fellow at the International Max Planck Research School "Moral Economies of Modern Societies" and is currently Junior Fellow at the Internationales Forschungszentrum Kulturwissenschaften der Kunstuniversität Linz in Wien. His dissertation deals with re-integration of disabled veterans in Cisleithania during the First World War. His research focusses on gender history, disability studies and cultural history of administration in Central Europe. An article on the moral economy of the reintegration efforts for disabled veterans is forthcoming in a special issue of Geschichte und Gesellschaft edited by Ute Frevert. 